\title{
Impacts of corporate governance on Asian REITs performance
}

\begin{abstract}
The results indicate that corporate governance not only helps to improve the return on assets (ROA) but also helps to gauge excess returns of REITs even though the Asian REIT industry is a highly regulated industry. The findings also found that REIT organization, remuneration matters and fees decrease the performance of Asian REITs. However, gearing and related party transactions are found to enhance the performance and accelerate the growth of REITs. Besides that, board matters, audit and fees have significant negative impacts on Tobin's q. Also audit is found to reduce the returns of Asian REITs. However, interestingly, the ownership has significant positive impact on Tobin's q. In addition, the block ownership also helps to curtail and mitigate excess returns of REITs in Asia. This also implies that unitholders are generally and minimally protected. The findings imply that the REIT managers face substantial cost in adjusting to equilibrium level whereby the optimum level is always dynamic and not constant, and it persists over time. This also implies that agency costs exist in the existing externally managed REIT structure in Asian REITs. This also implies that Asian REITs could consider redefining the REIT management structure such as the internally managed REIT structure. The findings of this study indicated the need for improvements, transformation and reform in the REIT regime in order to increase the transparency and disclosure of corporate governance of REITs that could facilitate continuous strategic development and growth of REITs in Asia.
\end{abstract}

Keyword: REIT corporate governance; Individual corporate governance attribute; Performance; Excess return; Asian REITs; GMM method 